\title{
Effect of Traditional Household Processes on Iron, Zinc and Copper Bioaccessibility in Black Bean (Phaseolus vulgaris L.)
}

\author{
Sabrina Feitosa ${ }^{1,2, *(1)}$, Ralf Greiner ${ }^{1}$, Ann-Katrin Meinhardt ${ }^{1}$, Alexandra Müller ${ }^{1}$, \\ Deusdélia T. Almeida ${ }^{2}$ and Clemens Posten ${ }^{3}$ \\ 1 Department of Food Technology and Bioprocess Engineering, Max Rubner-Institut, \\ Federal Research Institute of Nutrition and Food, Haid-und-Neu-Str. 9, D-76131 Karlsruhe, Germany; \\ ralf.greiner@mri.bund.de (R.G.); ann-katrin.meinhardt@mri.bund.de (A.-K.M.); \\ alexandra.mueller@mri.bund.de (A.M.) \\ 2 School of Nutrition, Federal University of Bahia, Av. Araújo Pinho 32, Salvador 40110-150, Brazil; \\ deliata@uol.com.br \\ 3 Institute of Life Science Engineering, Bioprocess Engineering, University of Karlsruhe, Fritz-Haber-Weg 2, \\ 76131 Karlsruhe, Germany; clemens.posten@kit.edu \\ * Correspondence: sabrinafeitosa0@gmail.com; Tel.: +49-(0)721-6625-328
}

Received: 29 June 2018; Accepted: 30 July 2018; Published: 31 July 2018

\begin{abstract}
Micronutrient deficiencies are a major public health problem. Beans are an important plant-based source of iron, zinc and copper, but their absorption is reduced in the presence of anti-nutrients such as phytates, polyphenols and tannins. Soaking and discarding the soaking water before cooking is unanimously recommended, but this can result in mineral loss. Data on the consequences for mineral bioaccessibility is still limited. This study aimed to evaluate iron, zinc and copper bioaccessibility in black beans cooked (regular pan, pressure cooker) with and without the soaking water. For that, three batches of black beans were investigated in triplicate, each split in nine parts (raw grains and four different household processes in duplicate) and analyzed by applying the quarter technique, resulting in a grand total of 164 samples. Minerals were quantified by ICP-MS (inductively coupled plasma mass spectrometry), myo-inositol phosphates ( $\operatorname{Ins}_{5}, \operatorname{InsP}_{6}$ ) by HPLC (high-performance liquid chromatography) ion-pair chromatography, total polyphenols using Folin-Denis reagent and condensed tannins using Vanillin assay. Mineral bioaccessibility was determined by in vitro digestion and dialysis. All treatments resulted in a statistically significant reduction of total polyphenols $(30 \%)$ and condensed tannins $(20 \%)$. Only when discarding the soaking water a loss of iron (6\%) and copper (30\%) was observed, and $\mathrm{InsP}_{6}$ was slightly decreased $(7 \%)$ in one treatment. The bioaccessibility of iron and zinc were low (about $0.2 \%$ iron and $35 \%$ zinc), but copper presented high bioaccessibility (about 70\%). Cooking beans under pressure without discarding the soaking water resulted in the highest bioaccessibility levels among all household procedures. Discarding the soaking water before cooking did not improve the nutritional quality of the beans.
\end{abstract}

Keywords: beans; iron; zinc and copper bioaccessibility; myo-inositol phosphates; anti-nutrients; polyphenols; household processing

\section{Introduction}

Deficiencies of micronutrients are a major public health problem, in which iron and zinc malnutrition affects more than half of the population worldwide [1,2]. Iron-deficiency anemia reaches more than $30 \%$ of the world's population, approximately $20 \%$ in European Union and up to $40 \%$ in 
developing countries [1,3]. It contributes to $20 \%$ of maternal deaths besides being related to low adult productivity at work [3,4]. Outcomes of zinc deficiency are depressed growth, immune dysfunction, lower respiratory tract infections, diarrhea, altered cognition and other clinical conditions [4,5]. Copper deficiency may also lead to anemia, but features of human copper deficiency mechanisms are still unknown [6], while most copper research is focused on soil, fruits and nuts e.g., [7,8].

The major reason for iron deficiency is a poor availability of iron from the diet. Mineral deficiencies are not only caused by low dietary intake. Many other factors affect the absorption such as the total content of the minerals and anti-nutrients, the processing applied and mineral interactions $[9,10]$. The interactions concerning iron, zinc and copper appear to be especially important, and the bioaccessibility is influenced differently depending on the mineral [11,12]. Dietary and human factors, such as inflammation and disease, have been found to be the major factors influencing the bioavailability of micronutrients. Dietary factors are related to food matrix structure and composition, being mostly influenced by the interaction with other dietary compounds, such as fibers, lipids, proteins and anti-nutrients during digestion and absorption. It is also important to consider not only the total content of iron, zinc and copper in crops, but also the tissue localization (cotyledon and endosperm) and specification (chelates and protein particles) [11,13]. Iron exists in two different forms in food: hemic iron in animal products and non-hemic iron in plant foods which is generally poorly absorbed. Iron is stored in plants and animals as the protein ferritin, and about $80 \%$ of the iron in beans is present in the form of non-ferritin-bound iron which is possibly bound to myo-inositol phosphates [11,14]. Condensed tannins are able to form tannin-protein complexes that can chelate iron and calcium. Animal studies have demonstrated that in the presence of phytate, calcium can impair zinc absorption, probably by co-precipitation with phytate and zinc. Furthermore, digestibility and hence absorption of micronutrients such as iron and zinc can be improved upon heat processing, which results in softening of the food matrix, with release of protein-bound iron and zinc, thus facilitating its absorption. Studies in human subjects have shown that zinc may stimulate iron absorption, and calcium can inhibit iron absorption by inhibiting iron transport. Copper is essential for iron transport between tissues in which iron and copper homeostases are linked by the inability to export iron to the systemic circulation in the absence of copper. On the mechanistic level, neither zinc nor calcium seem to be as crucial for iron absorption as copper, but there are only few studies about copper deficiency and sufficient copper levels in the diet $[6,11,12]$.

Beans are highly nutritious and the most consumed leguminous grain worldwide, which are an important plant-based source of iron, zinc and copper [15-17]. They are part of many traditional diets, playing a major role in vegetarian diets in all countries, besides being consumed in different dishes together with other food products $[9,15,17,18]$. Therefore, mineral bioavailability may also be influenced by interference with other food constituents $[9,10]$. Common beans are a staple food in Latin America and Eastern Africa $[19,20]$ and Brazil is the most important consumer of beans in the world, with up to $19 \mathrm{~kg}$ /year per capita consumption, $80 \%$ of which is common bean and black bean is the second most consumed [17,21]. Approximately, a portion per meal of cooked beans $(100 \mathrm{~g})[15,17]$ contains $6.52-10.00 \mathrm{mg}$ iron, $0.93-1.21 \mathrm{mg}$ copper and 3.18-3.60 mg zinc, which equals the daily requirements for healthy adults for iron and copper and half of that of zinc $(8 \mathrm{mg} /$ day, $0.9 \mathrm{mg} /$ day and $8-11 \mathrm{mg} /$ day, respectively) [22]. Therefore, a regular intake of beans could contribute to minimize deficiencies of micronutrients $[15,17]$. The nutritional quality of beans, however, is usually reduced by the presence of anti-nutrients, such as phytates, polyphenols and tannins $[9,20]$. Those compounds bind to minerals such as iron, zinc, copper, calcium and magnesium, thus reducing bioavailability due to the formation of extremely insoluble salts or very poorly dissociated chelates.

Phytates $\left(\mathrm{InsP}_{6}\right)$, have especially been reported to affect iron and zinc absorption negatively even at low concentrations [9,23-25]. Condensed tannins are able to form tannin-protein complexes, which can chelate iron and calcium $[9,26,27]$. A reduction of mineral bioavailability was observed when condensed tannins concentration was higher than $10 \%$ of the total dry weight of the samples or ranging from 2.5 to $4.7 \mathrm{mg}$ eq. $\mathrm{CE} \mathrm{g}^{-1}[27,28]$. With regard to polyphenolic compounds, it has been 
reported that they reduce bioavailability of some minerals. Although there is no consensus on the quantity needed to decrease iron absorption in beans, a reduction in iron bioavailability was observed above $50 \mathrm{mg}$ of polyphenols [27,29]. Furthermore, the polyphenols in legumes have been extensively correlated with health benefits in humans due to their potent anti-oxidant activities [30,31]. In common beans, those bioactive compounds mostly comprise phenolic acids and condensed tannins which are found in the cotyledons, and exhibit anti-diabetic, anti-obesity, anti-inflammatory, anti-mutagenic and anti-carcinogenic effects [30-32].

In a recent study [33], polyphenols of black beans were individually examined for their effect on iron uptake by Caco-2 cells. Half of the polyphenols studied were shown to inhibit iron absorption, but the other half were found to clearly promote iron absorption. So far, many studies $[23,24,27,34]$ reported the link between a reduction of the total content of anti-nutrients in food grains with a higher availability of iron and zinc. Food processing and food preparation techniques like soaking, germination, hydrothermal treatment and fermentation can reduce the content of anti-nutrients $[9,25,34]$. Soaking and discarding the soaking water before cooking beans has been unanimously recommended due to a higher reduction of the anti-nutrients. An average reduction of $20 \%$ to $30 \%$ of condensed tannins and total polyphenols can be obtained in legumes by applying household processes $[27,34,35]$. The effect on mineral bioavailability was assessed in those studies mainly by molar ratios and statistical correlations between the content of anti-nutrients and the mineral content $[27,34,35]$. In general, digestibility and not bioavailability assays were applied in those studies. Bioavailability and bioaccessibility are often used indistinctly [36].

Only direct feeding trials can fully determine biological efficacy and mineral interactions, but they are long-lasting, cost intensive, and nonetheless the results need to be extrapolated to the human organism. A simple method to estimate the effect of for example food processing on mineral bioavailability is the use of bioaccessibility assays $[19,24]$. Although there is a substantial amount of information about binding of iron and zinc, and anti-nutrients reduction by food processing, data on the consequences for mineral absorption are still limited. Discarding the soaking water before cooking beans can result in loss of minerals and anti-oxidants and thus the nutritional quality of cooked beans is not necessarily improved. Thus, this study aimed to evaluate iron, zinc and copper bioaccessibility in black beans cooked with and without the soaking water using traditional household processes in order to expand knowledge about the nutritional value of this basic and accessible food and the options to use beans in combating micronutrients deficiencies.

\section{Materials and Methods}

All glassware used in sample preparation and analyses was washed in distilled water and for mineral analysis also immersed in a $5 \%$ nitric acid solution for more than $1 \mathrm{~h}$ and rinsed with ultrapure water (Milli-Q, Millipore, Merck KGaA, Darmstadt, Germany). The following describes in details the methods for analyzing three batches of black beans in triplicate, each split in nine parts (raw grains and four different household processes in duplicate), which were studied by applying the quarter technique, resulting in a total of 164 samples.

\subsection{Samples}

Three different batches of common beans (Phaseolus vulgaris L., black bean variety) from three randomly selected markets in Rio de Janeiro, Brazil, were used in this study. All batches were from commercial cultivation, geographic origin in the region of São Paulo, $-23^{\circ} 10^{\prime} 45^{\prime \prime} \mathrm{S}, 45^{\circ} 53^{\prime} 12^{\prime \prime} \mathrm{W}$, and harvested in June-July of 2015. The procedures applied during growth of the crop were not available. Moreover, the influence of the crop season on the black beans of this study is negligible [37]. The black bean samples were sent to Germany (Max Rubner-Institut, Karlsruhe, Germany), where the study (including the household processing) was performed in a period of one year, in a controlled environment to mitigate the influence of seasons to the experiment. The samples were stored at $4{ }^{\circ} \mathrm{C}$ with an extra vacuum-packaging. The raw grains were cleaned before use. All dirt was removed 
manually and then the beans were washed with deionized water. After that, the beans were cooked. For analyses the samples were freeze-dried (developed at the Max Rubner-Institut, Karlsruhe, Germany, operating with an air temperature of $-30^{\circ} \mathrm{C}$ and air velocity of $6 \mathrm{~ms}^{-1}$ ) and finely ground in a stainless steel analytical grinder (A10 Yellow Line, IKA-Werke GmbH \& Co. KG, Staufen, Germany). Thereafter, a quarter technique was applied to the raw grains and the cooked beans together with the broth in order to obtain two final fractions properly homogenized. Each analytical determination was carried out in triplicate for each fraction of cooked and raw samples.

\subsection{Household Treatments}

In order to simulate traditional household processes for cooking beans, an overnight soaking (12 h) at room temperature was performed, followed by two cooking methods (boiling and pressure cooking) in tap water. Three different batches of black beans were used. A proportion of $100 \mathrm{~g}$ of the black beans and $400 \mathrm{~mL}$ of water were used for soaking. The following cooking strategies were performed: (1) with the soaking water in a pressure cooker; (2) without the soaking water in a pressure cooker; (3) with the soaking water in a regular pan; and (4) without the soaking water in a regular pan. The regular pan had a capacity of $3 \mathrm{~L}$ and the beans were cooked for $35 \mathrm{~min}$. $200 \mathrm{~mL}$ of tap water were added during cooking to replenish the loss of evaporated water. The pressure cooker had a capacity of $3 \mathrm{~L}$ and the beans were cooked for $5 \mathrm{~min}$. No water was added during the cooking process. The cooking times were chosen according to the results of a test cooking simulation. Before cooking the black beans, either tap water was added to the soaking water to give a final volume of $600 \mathrm{~mL}$ or the soaking water was discarded and replaced by tap water to give a final volume of $600 \mathrm{~mL}$. All treatments were performed in duplicate for each batch of black beans. The same cooking methods were also performed without bean samples to quantify the concentrations of the minerals in the water before and after the cooking process.

\subsection{Myo-Inositol Phosphates}

Quantification of myo-inositol phosphates was performed by extracting $1 \mathrm{~g}$ of a freeze-dried sample with $20 \mathrm{~mL}$ of $2.4 \% \mathrm{HCl}$ for $3 \mathrm{~h}$ with constant shaking at room temperature. The resulting suspensions were centrifuged (30 min, 15,000 rpm). The supernatant was collected and used for myo-inositol phosphate quantification [38]; $2 \mathrm{~mL}$ of the supernatant were diluted with ultrapure water to give a final volume of $60 \mathrm{~mL}$. The entire solution was applied to a column $(0.7 \times 15 \mathrm{~cm})$ containing $0.5 \mathrm{~g}$ of AG 1-X4 100-200-mesh resin (Bio-Rad Laboratories GmbH, München, Germany). The column was washed with $25 \mathrm{~mL}$ of ultrapure water and $25 \mathrm{~mL}$ of $25 \mathrm{mM} \mathrm{HCl}$. Then myo-inositol phosphates were eluted with $25 \mathrm{~mL}$ of $2 \mathrm{M} \mathrm{HCl}$. The eluates obtained were concentrated in a vacuum evaporator (Rotavapor RE-120, BÜCHI Labortechnik AG, Flawil, Switzerland) (at $40^{\circ} \mathrm{C}$ ) and dissolved in $1 \mathrm{~mL}$ of ultrapure water. Then $20 \mu \mathrm{L}$ of the samples were chromatographed on Ultrasep ES $100 \mathrm{RP} 18$ $(2 \times 250 \mathrm{~mm})$. The column was run at $40{ }^{\circ} \mathrm{C}$ and $0.2 \mathrm{~mL} \mathrm{~min}^{-1}$ of an eluent consisting of formic acid/methanol/water/tetrabutylammonium hydroxide (44:56:5:1.5 v/v), $\mathrm{pH}$ 4.25. A mixture of the individual myo-inositol phosphate esters $\left(\mathrm{InsP}_{3}-\mathrm{InsP}_{6}\right)$ was used as a standard [39]. The retention times of $\mathrm{InsP}_{5}$ and $\mathrm{InsP}_{6}$ were $15 \mathrm{~min}$ and $23 \mathrm{~min}$, respectively.

\subsection{Total Polyphenols}

Total phenols were extracted with water. An internal standard curve was prepared by adding $10 \mathrm{~mL}$ of $0-0.01 \%$ tannic acid to the flasks. The flasks were heated for $30 \mathrm{~min}$ at $70{ }^{\circ} \mathrm{C}$ with constant shaking. Clear supernatants were collected after centrifugation at $2500 \mathrm{~g}$ for $15 \mathrm{~min}$ followed by filtration. Polyphenols were determined using the Folin-Denis reagent [40].

\subsection{Condensed Tannins}

Condensed tannins were extracted with $\mathrm{HCl}$ :methanol $(1: 100 v / v)$ for $2 \mathrm{~h}$ with mechanical shaking (Universal shaker SM, Carl Roth $\mathrm{GmbH}+\mathrm{Co}$. KG, Karlsruhe, Germany) at $25^{\circ} \mathrm{C}$ and centrifuged 
(Sorvall LYNX 6000, Thermo Scientific, Langenselbold, Germany) at $5000 \mathrm{~g}$ at $15^{\circ} \mathrm{C}$ for $15 \mathrm{~min}$. Aliquots were immediately analyzed for tannins using the $0.5 \%$ vanillin assay [41].

\subsection{Minerals}

Iron $(\mathrm{Fe})$, zinc $(\mathrm{Zn})$, copper $(\mathrm{Cu})$ and calcium $(\mathrm{Ca})$ concentrations were measured. Therefore, $150 \mathrm{mg}$ of each ground sample was microwave-digested in a MWS-1 (Berghof Products + Instruments $\mathrm{GmbH}$, Eningen, Germany) with $3 \mathrm{~mL}$ of concentrated $\mathrm{HNO}_{3}(65 \% v / v)$ and $0.75 \mathrm{~mL}$ of $\mathrm{H}_{2} \mathrm{O}_{2}(30 \% v / v)$. Heating was performed in four successive steps: linear temperature increased up to $150{ }^{\circ} \mathrm{C}$ in $5 \mathrm{~min}$ $(80 \mathrm{~W}) ; 5 \mathrm{~min}$ at $150{ }^{\circ} \mathrm{C}(70 \mathrm{~W})$; linear temperature increased up to $180^{\circ} \mathrm{C}$ in $40 \mathrm{~min}(80 \mathrm{~W}) ; 10 \mathrm{~min}$ at $180^{\circ} \mathrm{C}(80 \mathrm{~W})$. All samples were analyzed in triplicate and a set of digestion blanks were prepared with each sample batch. The data was expressed as mean \pm standard deviation on dry matter (DM) basis.

Element analysis was performed by inductively coupled plasma mass spectrometry (ICP-MS), iCAP Q (Thermo Scientific, Waltham, MA, USA). The ICP-MS operating conditions and measurement parameters are given in Table 1. Standard addition was used for calibration. The limit of quantification (LOQ) was calculated based on the measured values of the blanks $(n=152)$, where LOQ $=$ mean $+10 \times$ standard deviation. The extreme studentized deviate test was used to remove outliers from the data set. Fresh kidney beans NCS ZC73019 (GSB-12) was used as reference material $(n=84)$ to determine precision and accuracy of the method (Table 2). The relative standard deviations were less than $3 \%$ for all investigated elements, and at a $95 \%$ confidence level showed that there was no significant difference between the means of the certified and determined values for the analytes under investigation.

Table 1. ICP-MS operating conditions and measurement parameters.

\begin{tabular}{cc}
\hline Parameter & Value \\
\hline Radiofrequency power & $1550 \mathrm{~W}$ \\
Argon flow rates & \\
Cooling & $13.8 \mathrm{~L} \mathrm{~min}^{-1}$ \\
Auxiliary & $0.65 \mathrm{~L} \mathrm{~min}^{-1}$ \\
Nebulizer & $1.05 \mathrm{~L} \mathrm{~min}^{-1}$ \\
Sample cone & $\mathrm{Ni}$ \\
Skimmer cone & $\mathrm{Ni}$ \\
Analyte & 43Ca, 56Fe, 65Cu, 66Zn \\
Internal standard & $\mathrm{STD}(\mathrm{Ca}), \mathrm{KED}(\mathrm{Fe}, \mathrm{Cu}, \mathrm{Zn})$ \\
Aquisition/scanning mode & 100 \\
Sweeps per reading & $10 \mathrm{~ms}(\mathrm{Ca}, \mathrm{Cu}, \mathrm{Zn}) ; 40 \mathrm{~ms}(\mathrm{Fe})$ \\
Dwell time & 5 \\
No. of runs & $21 \mathrm{~s}$ \\
Replicate time & 103Rh $(\mathrm{Fe}, \mathrm{Cu}, \mathrm{Zn}), 45 \mathrm{Sc}(\mathrm{Ca}, \mathrm{Fe}), 89 \mathrm{Y}(\mathrm{Fe}, \mathrm{Cu}), 72 \mathrm{Ge}(\mathrm{Ca}, \mathrm{Zn}), 15 \mathrm{In}(\mathrm{Cu}, \mathrm{Zn})$ \\
Sample uptake rate & $0.2 \mathrm{~mL} \mathrm{~min}-1$ \\
between samples $\left(2 \% \mathrm{HNO}_{3}\right)$ & $30 \mathrm{~s}$ \\
Sample delay & $50 \mathrm{~s}$ \\
Stabilization time & $5 \mathrm{~s}$ \\
\hline
\end{tabular}

ICP-MS: Inductively Coupled Plasma Mass Spectrometry.

Table 2. ICP-MS precision and accuracy of the method.

\begin{tabular}{|c|c|c|c|}
\hline Element & LOQ $\left(\mu \mathrm{g} \mathrm{kg}^{-1}\right)$ & Reference Material Measured Value $\left(\mathrm{mg} \mathrm{kg}^{-1}\right)$ & Reference Material Certificate Value $\left(\mathrm{mg} \mathrm{kg}^{-1}\right)$ \\
\hline $\mathrm{Ca}$ & 29.8 & $0.66 \pm 0.06$ & $0.67 \pm 0.04$ \\
\hline $\mathrm{Fe}$ & 1.8 & $306 \pm 29$ & $330 \pm 20$ \\
\hline $\mathrm{Cu}$ & 7.2 & $8.4 \pm 1.5$ & $8.7 \pm 0.5$ \\
\hline $\mathrm{Zn}$ & 6.6 & $34 \pm 4$ & $32 \pm 2$ \\
\hline
\end{tabular}

\subsection{Iron, Zinc and Copper Bioaccessibility}

In order to be able to quantify bioaccessibility in cooked black bean samples, a simplified in vitro gastrointestinal digestion assay was carried out. Iron, zinc and copper bioaccessibilities 
were determined based on in vitro digestion and dialysis method described by [42] with modifications. For gastric digestion, $10 \mathrm{~g}$ of ground sample were suspended in $60 \mathrm{~mL}$ of $20 \mathrm{mM}$ glycine- $\mathrm{HCl}$ buffer, $\mathrm{pH}$ 2.0. After, adjusting $\mathrm{pH}$ to 2.0 by with $2 \mathrm{M} \mathrm{HCl}, 1.3 \mathrm{~mL}$ of pepsin (porcine, Fluka Analytical, Sigma-Aldrich Chemie $\mathrm{GmbH}$, Steinheim, Germany) solution (1.6 g pepsin in $10 \mathrm{~mL} 20 \mathrm{mM}$ glycine- $\mathrm{HCl}$ buffer, $\mathrm{pH}$ 2.0) were added. The suspension was incubated at $37^{\circ} \mathrm{C}$ for $2 \mathrm{~h}$ under agitation. To simulate intestinal digestion, the $\mathrm{pH}$ of the gastric digestion was adjusted to 7.2 with $1 \mathrm{M}$ $\mathrm{NaHCO}_{3} .13 \mathrm{~mL}$ of a pancreatin (porcine, P1750, Sigma-Aldrich Chemie GmbH, Steinheim, Germany) solution ( $0.4 \mathrm{~g}$ pancreatin in $100 \mathrm{~mL}$ of ultrapure water) were added and a dialysis bag (cut of 10,000 Da; Carl Roth GmbH + Co. KG, Karlsruhe, Germany, containing $2 \mathrm{~mL}$ of ultrapure water) was placed in the digestion system. The system was incubated at $37^{\circ} \mathrm{C}$ for $2 \mathrm{~h}$, under agitation. Thereafter, the dialysis bag was removed and iron, zinc and copper in the dialysate were analyzed by ICP-MS. Bioaccessibility $(\%)$ was calculated as $100 \times \mathrm{Y} / \mathrm{Z}$ whereby $\mathrm{Y}$ represents the dialyzable amount of the mineral per $100 \mathrm{~g}$ $\mathrm{DM}$ of cooked beans and $\mathrm{Z}$ the total of the same mineral per $100 \mathrm{~g}$ DM of the cooked beans.

\subsection{Statistical Analysis}

All the analyses were conducted in triplicate and expressed as mean \pm standard deviation of three separate determinations. The results were evaluated for normality by the Shapiro-Wilk test. The data generated was subjected to one-way analysis of variance (ANOVA) using the software Sigma Plot version 13.0. A Tukey's paired comparison test was used to determine statistically significant differences $(p<0.05)$ among the batches and in between raw and treated samples mean values, at a 95\% confidence level.

\section{Results and Discussion}

\subsection{Mineral Contents of Raw and Cooked Beans}

The mean iron, zinc, copper and calcium contents of the three black bean batches are presented in Figure 1. All batches were not significantly different $(p>0.05)$ among each other.

Black beans were confirmed to be a good source of iron, zinc and copper. Approximately a portion per meal of cooked black beans ( $100 \mathrm{~g})$ contains an average of $6.5 \mathrm{mg}$ iron, $4 \mathrm{mg}$ zinc and $1 \mathrm{mg}$ copper. Those contents are in good agreement with data published by the Food and Agriculture Organization of the United Nations database [15] for common beans of the same origin. Thus, $100 \mathrm{~g}$ of black bean meets the daily requirement for copper $(0.9 \mathrm{mg}$ /day $)$, and partially that for iron $(8 \mathrm{mg} /$ day $)$ and zinc (8-11 mg/day) [22].

Discarding the soaking water before cooking the beans resulted in a lower content $(p<0.001)$ of iron $(6 \%)$ and copper (30\%) compared to the raw beans (Figure 1A,B). According to Raes et al. [13], the differences in leaching of micronutrients can be attributed to the fact that these minerals are bound by different food constituents with different binding strength. Furthermore, their location within the food matrix might be different. Zinc and calcium contents was found to be increased irrespective of the household procedure applied $(p<0.001)$. The highest contents (Zn: 132-150\%, Ca: 191\%) were found in black beans cooked in a regular pan (Figure 1C,D).

The concentrations of the minerals in the water before and after the cooking process were measured and hence either present in the tap water or released from the pressure cooker or pan. Iron and copper concentrations of the tap water before and after cooking were below the LOQ $\left(\mathrm{mg} 100 \mathrm{~g}^{-1}\right)$ : $\mathrm{Fe}(0.14), \mathrm{Cu}(0.56)$. Zinc mean concentrations were determined to be below the LOQ $\left(0.51 \mathrm{mg} 100 \mathrm{~mL}^{-1}\right)$ in the tap water. In the boiled water samples, it ranged from $0.75 \pm 0.06 \mathrm{mg}$ (pressure cooker) to $1.92 \pm 0.32 \mathrm{mg}$ (regular pan). Therefore, the increase in the $\mathrm{Zn}$ contents was found to be due to a leaching of zinc ions from the pan surface. A smaller increase $(p<0.05)$ in $\mathrm{Zn}$ content (123-125\%) was also observed during pressure cooking (Figure 1C). Katzenberg et al. [43], also reported higher zinc concentrations in beef as an effect of the cooking method and Quintaes et al. [44], have shown the migration of metal ions from cookware into foods. 

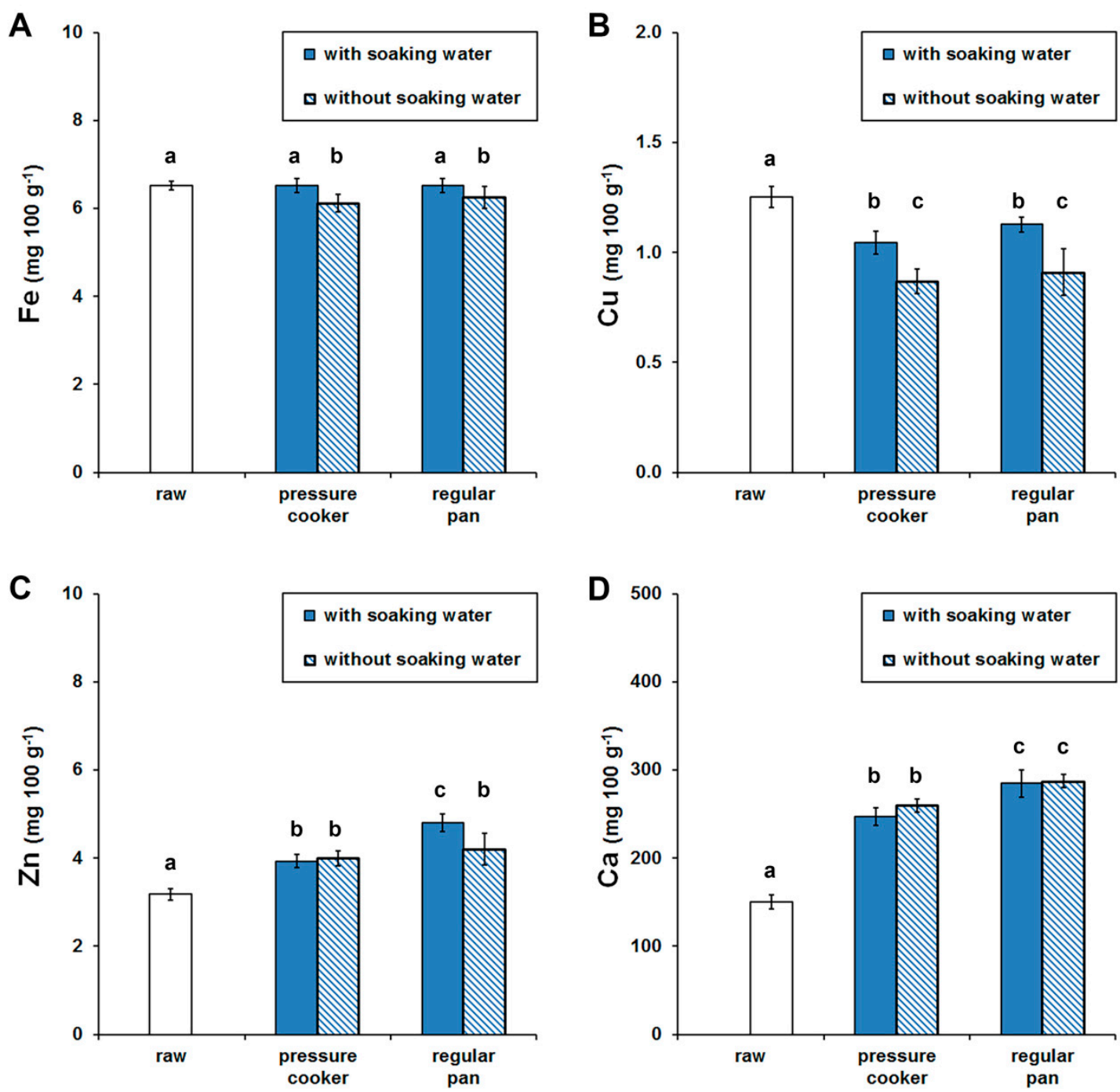

Figure 1. Black bean contents of iron (A), copper (B), zinc (C) and calcium (D). Data expressed as mean \pm standard deviation (dry matter). Values marked by different letters are significantly different $(p<0.05)$.

The mean Ca concentration in the tap water was determined to be $16.83 \pm 1.38 \mathrm{mg} 100 \mathrm{~mL}^{-1}$.

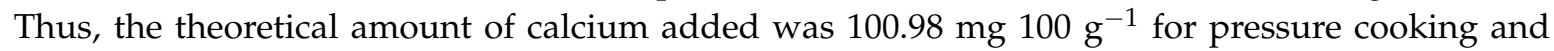
$134.64 \mathrm{mg} 100 \mathrm{~g}^{-1}$ in the regular pan. The observed increases in calcium were found to be

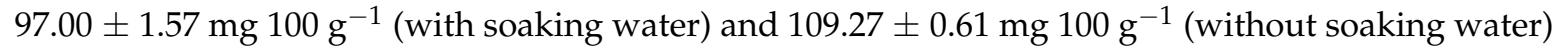
for pressure cooking, and $134.66 \pm 7.23 \mathrm{mg} 100 \mathrm{~g}^{-1}$ (with soaking water) and $136.95 \pm 0.80 \mathrm{mg}^{100 \mathrm{~g}^{-1}}$ (without soaking water) using the regular pan (Figure 1D). Therefore, the increase in Ca contents was due to the addition of tap water during cooking.

\subsection{Anti-Nutrients}

The mean contents of $\mathrm{InsP}_{6}, \mathrm{InsP}_{5}$, total polyphenols and condensed tannins are presented in Figure 2. All traditional household processes applied resulted in a statistically significant reduction in total polyphenols (about 30\%) and condensed tannins (about 20\%) compared to raw black bean (Figure 2C,D). Discarding the soaking water before cooking the beans resulted in a greater reduction of polyphenols and tannins, which is in good accordance with the majority of studies [27,34]. Since polyphenols of legumes have been extensively correlated with health benefits in humans due to their potent anti-oxidant activities [30-32], their reduction during processing does not necessarily 
improve the nutritional quality of beans. With regard to myo-inositol phosphates, only with beans cooked without the soaking water in a pressure cooker a slightly decrease $(7 \%)$ in $\mathrm{InsP}_{6}$ content was observed. InsP $\mathrm{P}_{5}$ contents, however, increased with all cooking procedures applied. Furthermore, no statistical difference was observed among the three batches of the black bean samples regarding the contents of anti-nutrients.
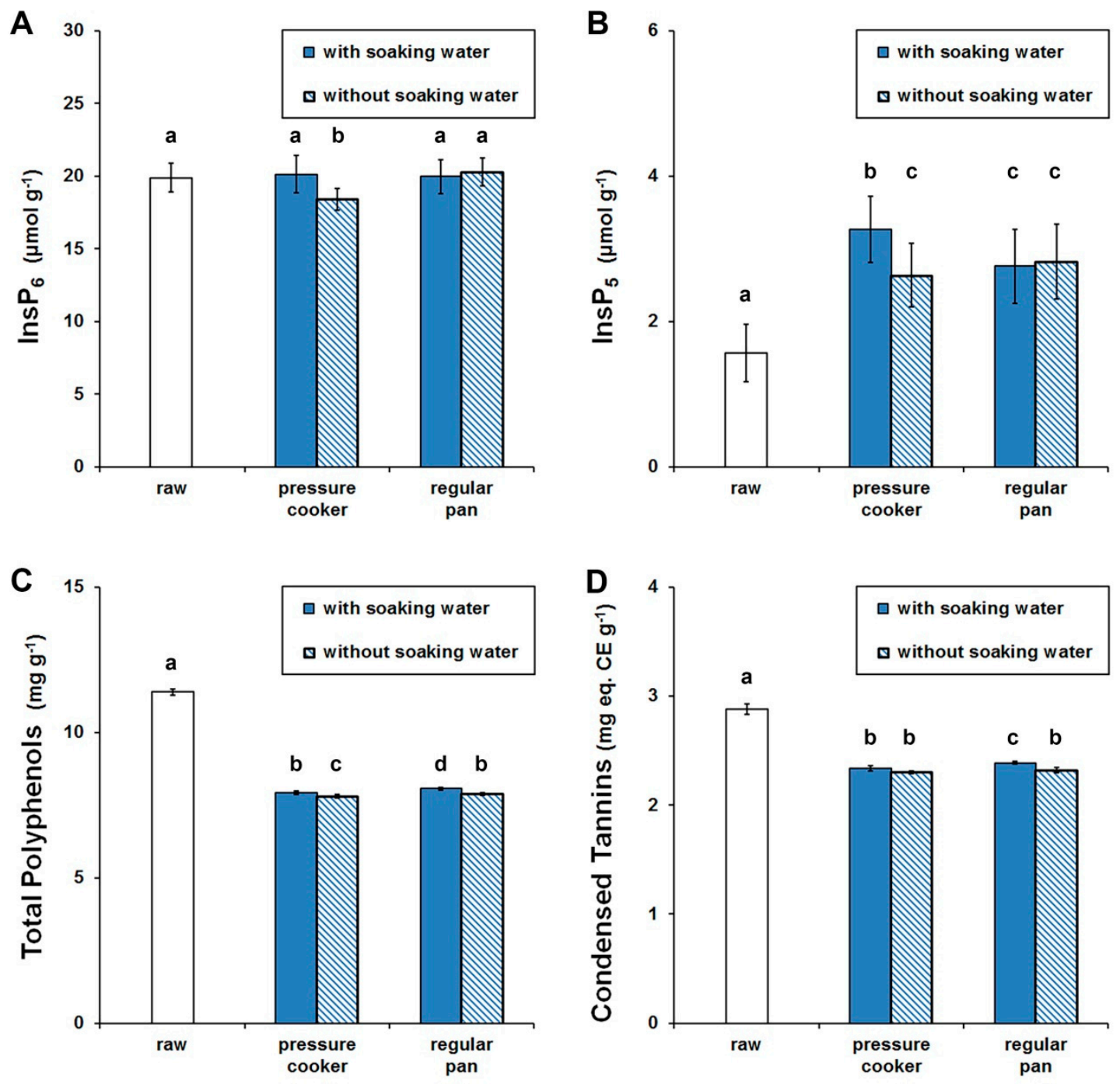

Figure 2. Black bean anti-nutrients content of $\operatorname{InsP}_{6}(\mathbf{A}), \operatorname{InsP}_{5}(\mathbf{B})$, total polyphenols $(\mathbf{C})$ and condensed tannins (D). Data expressed as mean \pm standard deviation (dry matter). Values marked by different letters are significantly different $(p<0.05)$.

\subsection{Bioaccessibility of Iron, Zinc and Copper}

The mean levels (\%) of iron, zinc and copper bioaccessibility in cooked black beans are shown in Table 3. The determination of the micronutrient bioaccessibility makes it possible to estimate the percentage of absorption of those minerals with a simple and affordable assay compared to bioavailability assessment. Beans are highly nutritious legumes that have been reported as one of the best plant-based sources of bioaccessible iron and zinc [18-20]. In this study however, iron bioaccessibility levels were found to be low with all household processes (Table 3). On the other hand, copper showed high bioaccessibility, followed by zinc (Table 3). 
Table 3. Bioaccessibility levels (\%) of iron, zinc and copper in black bean cooked with traditional household processes.

\begin{tabular}{cccc}
\hline Household Processes & Iron (\%) & Zinc (\%) & Copper (\%) \\
\hline Regular pan with soaking water & $0.18^{\mathrm{a}}$ & $33.94^{\mathrm{a}}$ & $71.53^{\mathrm{a}}$ \\
Pressure cooker with soaking water & $0.33^{\mathrm{b}}$ & $44.66^{\mathrm{b}}$ & $73.35^{\mathrm{a}}$ \\
Regular pan without soaking water & $0.17^{\mathrm{a}}$ & $31.55^{\mathrm{a}}$ & $66.42^{\mathrm{b}}$ \\
Pressure cooker without soaking water & $0.22^{\mathrm{a}}$ & $35.04^{\mathrm{a}}$ & $68.16^{\mathrm{b}}$ \\
\hline
\end{tabular}

In each column, values marked by different letters are a significantly different $(p<0.05)$.

Recent reviews $[27,34]$ reported a link between iron and zinc availability from common beans and cooking soaked beans without the soaking water. This was reported to be due to the reduction of the content in anti-nutrients during food processing [9]. In this present study, however, black bean cooked with the soaking water in a pressure cooker resulted in the highest bioaccessibility for all three minerals in spite of higher total anti-nutrients reduction in beans cooked without the soaking water. According to Hoppler et al. [14], 70-85\% of the iron in beans is present in the form of non-ferritin-bound iron and it is possibly bound to myo-inositol phosphates. Phytate is abundant in legumes, cereals and nuts, being considered to be the most powerful anti-nutrient due to their high binding capacity for metals and also their ability to form large insoluble aggregates [23,25].

Discarding the soaking water was shown to have a negative effect on the bioaccessibility of all three minerals in regular pan. Assessing mineral bioavailability in those studies mainly by molar ratios and statistical correlations between the content of anti-nutrients and the mineral content might be responsible for the observed differences in the obtained results [27,34,35]. In addition, details on the cooking methods applied were not reported. Pereira et al. [19], studied the effect of household cooking methods on the bioaccessibility of iron and zinc in different beans cultivars. Iron bioaccessibility of beans cooked with the soaking water in a pressure cooker were higher $(6.46-40.68 \%)$ compared to beans cooked in a regular pan (2.42-8.92\%). In the present study, the same tendency was observed. Even if lower Fe bioaccessibilities were found in this study, $\mathrm{Zn}$ bioaccessibilities were observed to be always higher than Fe bioaccessibilities. Bioaccessibility studies are a useful method to estimate the general trend of a household procedure on mineral bioavailability, but the absolute data obtained in those studies do not represent the situation in a human digestive tract. Neither active mineral uptake nor the interaction of minerals with respect to binding to food constituents or interaction with mineral transporters in the small intestine can be considered through bioaccessibility studies. The interactions concerning iron, zinc and copper appear to be of utmost importance in respect to their bioavailability [11,12]. Since micronutrient uptake has been successfully studied by Caco-2 cells models due to their exclusive ability to model human absorption characteristics [45-47], the data obtained in this study should be confirmed using a Caco-2 cell model.

\section{Conclusions}

Black beans were confirmed to be a good source of iron, zinc and copper with a high bioaccessibility of copper (about 70\%) from cooked beans. The bioaccessibility of iron and zinc, however, were found to be low (about $0.2 \%$ for iron and 35\% for zinc). Cooking beans under pressure without discarding the soaking water resulted in the highest bioaccessibility levels among all household procedures applied. Although a reduction in anti-nutrients' content was observed, the myo-inositol phosphate content did not change significantly. In addition, discarding the soaking water before cooking the beans did not improve their nutritional quality. This procedure resulted in a loss of iron, copper and bioactive compounds.

Data on the consequences for iron, zinc and copper absorption are still limited. Thus, improving knowledge about the influence of traditional household processes on the nutritional value of this basic and accessible food is important. Further work is necessary to increase especially iron availability in home-cooked beans. Since phytate is the constituent with the highest impact on 
mineral bioavailability in common beans, applying the most efficient household procedures combined with phytase application might be a promising approach.

Author Contributions: Conceptualization, Project Administration and Investigation, Funding Acquisition, Formal Analysis, Writing-Original Draft Preparation \& Visualization, S.F.; Writing-Review and Editing, R.G. and D.T.A.; Methodology, Data Curation, Review and Editing, A.-K.M., A.M., R.G. and S.F. Supervision, R.G. and C.P.

Funding: This research was funded by Conselho Nacional de Desenvolvimento Científico e Tecnológico (CNPq) grant number 234524/2014-6.

Acknowledgments: All technical support and materials used for experiments of the Max Rubner-Instiut and the Department of Food Technology and Bioprocess Engineering.

Conflicts of Interest: The authors declare no conflict of interest and the funders had no role in the design of the study, in the collection, analyses, or interpretation of data; in the writing of the manuscript, and in the decision to publish the results.

Limitations: Although this study was carefully conducted and has reached its aim, there was an unavoidable limitation. The specified information regarding what procedures were applied during growth of the crop is not available for the commercial cultivation of black beans used in this research. In addition, to mitigate the influence of seasons when the study was conducted, the experiments were performed entirely in a controlled environment.

\section{References}

1. World Health Organization (WHO). Nutrition Topics. Micronutrient Deficiencies. Available online: http: / / www.who.int/nutrition/topics/micronutrients/en/ (accessed on 23 May 2018).

2. World Health Organization (WHO). The World Health Report 2002: Reducing Risks, Promoting Healthy Life. Available online: http:/ / www.who.int/whr/2002/en/whr02_en.pdf (accessed on 23 May 2018).

3. World Health Organization (WHO). World Health Statistics. Available online: www.who.int/whosis/ whostat/2011/en/ (accessed on 23 May 2018).

4. World Health Organization (WHO). Global Health Risks, Part 2, Results. Available online: http:/ /www.who. int/healthinfo/global_burden_disease/GlobalHealthRisks_report_part2.pdf (accessed on 30 May 2018).

5. Hambidge, K.M. Mild zinc deficiency in human subjects. In Zinc in Human Biology; Mills, C.F., Ed.; Springer: New York, NY, USA, 1989; pp. 281-296.

6. Lazarchick, J. Update on anemia and neutropenia in copper deficiency. Curr. Opin. Hematol. 2012, 19, 58-60. [CrossRef] [PubMed]

7. Lamb, D.T.; Ming, H.; Megharaj, M.; Naidu, R. Heavy metal (Cu, Zn, Cd and Pb) partitioning and bioaccessibility in uncontaminated and long-term contaminated soils. J. Hazard Mater. 2009, 171, 1150-1158. [CrossRef]

8. Lima, A.C.S.; Soares, D.J.; Silva, L.M.R.; Figueiredo, R.W.; Sousa, P.H.M.; Menezes, E.A. In Vitro bioaccessibility of copper, iron, zinc and antioxidant compounds of whole cashew apple juice and cashew apple fibre (Anacardium occidentale L.) following simulated gastro-intestinal digestion. Food Chem. 2014, 161, 142-147. [CrossRef] [PubMed]

9. Sandberg, A.S. Bioavailability of minerals in legumes. Br. J. Nutr. 2002, 88, 281-285. [CrossRef]

10. Cozzolino, S.M.F. Biodisponibilidade de minerais. Rev. Nutr. 1997, 88, 87-98. [CrossRef]

11. Scheers, N. Regulatory effects of $\mathrm{Cu}, \mathrm{Zn}$, and $\mathrm{Ca}$ on Fe absorption: The intricate play between nutrient transporters. Nutrients 2013, 5, 957-970. [CrossRef] [PubMed]

12. Olivares, M.; Pizarro, F.; Ruz, M.; De Romaña, D.L. Acute inhibition of iron bioavailability by zinc: Studies in humans. Biometals 2012, 25, 657-664. [CrossRef]

13. Raes, K.; Knockaert, D.; Struijs, K.; Van Camp, J. Role of processing on bioaccessibility of minerals: Influence of localization of minerals and anti-nutritional factors in the plant. Trends Food Sci. Technol. 2014, 37, 32-41. [CrossRef]

14. Hoppler, M.; Zeder, C.; Walczyk, T. Quantification of ferritin-bound iron in plant samples by isotope tagging and species-specific isotope dilution mass spectrometry. Anal. Chem. 2009, 81, 7368-7372. [CrossRef] [PubMed]

15. Food and Agriculture Organization of the United Nations (FAO). FAO/INFOODS Global Food Composition Database for Pulses Version 1.0-uPulses 1.0. Available online: http:/ /www.fao.org/infoods/infoods/tablesand-databases/faoinfoods-databases/en/ (accessed on 30 April 2018). 
16. Akibode, S.; Maredia, M.K. Global and Regional Trends in Production, Trade and Consumption of Food Legume Crops; Michigan State University: East Lansing, MI, USA, 2011.

17. Lovato, F.; Kowaleski, J.; Silva, S.Z.; Heldt, L.F.S. Composição centesimal e conteúdo mineral de diferentes cultivares de feijão biorfortificado (Phaseolus vulgaris L.). Brazilian J. Food Technol. 2018, 21, 1-6. [CrossRef]

18. Suliburska, J.; Krejpcio, Z. Evaluation of the content and bioaccessibility of iron, zinc, calcium and magnesium from groats, rice, leguminous grains and nuts. J. Food Sci. Technol. 2014, 51, 589-594. [CrossRef] [PubMed]

19. Pereira, E.J.; Carvalho, L.M.; Dellamora-Ortiz, G.M.; Cardoso, F.S.; Carvalho, J.L. Effect of different home-cooking methods on the bioaccessibility of zinc and iron in conventionally bred cowpea (Vigna unguiculata L. Walp) consumed in Brazil. Food Nutr. Res. 2016, 60, 1-6. [CrossRef] [PubMed]

20. Petry, N.; Boy, E.; Wirth, J.P.; Hurrell, R.F. The potential of the common bean (Phaseolus vulgaris) as a vehicle for iron biofortification. Nutrients 2015, 7, 1144-1173. [CrossRef] [PubMed]

21. Companhia Nacional de Abastecimento (Conab). A Cultura do Feijão, 2018; Conab: Brasília, Brazil, 2018; ISBN 978-85-62223-12-9. Available online: http: / www.conab.gov.br (accessed on 19 July 2018).

22. Institute Medicine (US) Panel on Micronutrients. Dietary Reference Intakes for Vitamin A, Vitamin K, Arsenic, Boron, Chromium, Copper, Iodine, Iron, Manganese, Molybdenum, Nickel, Silicon, Vanadium, and Zinc. Available online: https:/ / www.ncbi.nlm.nih.gov/books/NBK222312/ (accessed on 8 March 2018).

23. Gupta, R.K.; Gangoliya, S.S.; Singh, N.K. Reduction of phytic acid and enhancement of bioavailable micronutrients in food grains. J. Food Sci. Technol. 2015, 52, 676-684. [CrossRef] [PubMed]

24. Gibson, R.S.; Bailey, K.B.; Gibbs, M.; Ferguson, E.L. A review of phytate, iron, zinc, and calcium concentrations in plant-based complementary foods used in low-income countries and implications for bioavailability. Food Nutr. Bull. 2010, 31, 134-146. [CrossRef] [PubMed]

25. Kumar, V.; Sinha, A.K.; Makkar, H.P.S.; Becker, K. Dietary roles of phytate and phytase in human nutrition: A review. Food Chem. 2010, 120, 945-959. [CrossRef]

26. Pedrosa, M.M.; Cuadrado, C.; Burbano, C.; Allaf, K.; Haddad, J.; Gelencsér, E.; Takács, K.; Guillamón, E.; Muzquiz, M. Effect of instant controlled pressure drop on the oligosaccharides, inositol phosphates, trypsin inhibitors and lectins contents of different legumes. Food Chem. 2012, 131, 862-868. [CrossRef]

27. Fernandes, A.C.; Nishida, W.; Da Costa Proença, R.P. Influence of soaking on the nutritional quality of common beans (Phaseolus vulgaris L.) cooked with or without the soaking water: A review. Int. J. Food Sci. Technol. 2010, 45, 2209-2218. [CrossRef]

28. Ghavidel, R.A.; Prakash, J. The impact of germination and dehulling on nutrients, antinutrients, In Vitro iron and calcium bioavailability and In Vitro starch and protein digestibility of some legume seeds. LWT-Food Sci. Technol. 2007, 40, 1292-1299. [CrossRef]

29. Petry, N.; Egli, I.; Zeder, C.; Walczyk, T.; Hurrell, R. Polyphenols and Phytic Acid Contribute to the Low Iron Bioavailability from Common Beans in Young Women. J. Nutr. 2010, 140, 1977-1982. [CrossRef] [PubMed]

30. Singh, B.; Singh, J.P.; Shevkani, K.; Singh, N.; Kaur, A. Bioactive constituents in pulses and their health benefits. J. Agric. Food Chem. 2017, 57, 4754-4764. [CrossRef] [PubMed]

31. Ganesan, K.; Xu, B. A critical review on polyphenols and health benefits of black soybeans. Nutrients 2017, 9, 455. [CrossRef] [PubMed]

32. Ramírez-Jiménez, A.K.; Reynoso-Camacho, R.; Tejero, M.E.; León-Galván, F.; Loarca-Piña, G. Potential role of bioactive compounds of Phaseolus vulgaris L. on lipid-lowering mechanisms. Food Res. Int. 2015, 76, 92-104. [CrossRef]

33. Hart, J.J.; Tako, E.; Kochian, L.V.; Glahn, R.P. Identification of black bean (Phaseolus vulgaris L.) polyphenols that inhibit and promote iron uptake by Caco-2 cells. J. Agric. Food Chem. 2015, 63, 5950-5956. [CrossRef] [PubMed]

34. Fabbri, A.D.T.; Guy, A.C. A review of the impact of preparation and cooking on the nutritional quality of vegetables and legumes. Int. J. Gastronomy Food Sci. 2016, 3, 2-11. [CrossRef]

35. Feitosa, S.; Korn, M.G.; Pinelli, M.; Oliveira, T.; Boffo, E.; Greiner, R.; Almeida, D.T. Content of Minerals and Antinutritional Factors in Akara (Fried Cowpea Food). Int. J. Food Process Technol. 2015, 2, 42-50. [CrossRef]

36. Etcheverry, P.; Grusak, M.A.; Fleige, L.E. Application of In Vitro bioaccessibility and bioavailability methods for calcium, carotenoids, folate, iron, magnesium, polyphenols, zinc, and vitamins B6, B12, D and E. Fron. Physiol. 2012, 3, 317. [CrossRef] [PubMed]

37. Perina, E.F.; Carvalho, C.R.L.; Chiorato, A.F.; Lopes, R.L.T.; Gonçalves, J.G.R.; Carbonell, S.A.M. Technological quality of common bean grains obtained in different growing seasons. Bragantia 2014, 73, 14-22. [CrossRef] 
38. AOAC. Phytate in Foods, Anion-Exchange Method, No. 986.11, 15th ed.; Official Methods of Analysis AOAC: Arlington, VA, USA, 1990; pp. 800-801.

39. Menezes-Blackburn, D.; Gabler, S.; Greiner, R. Performance of Seven Commercial Phytases in an In Vitro Simulation of Poultry Digestive Tract. J. Agric. Food Chem. 2015, 63, 6142-6149. [CrossRef] [PubMed]

40. King, H.G.; Health, G.W. The chemical analysis of small samples of leaf material and the relationship between disappearance and composition of leaves. Pedobiologia 1967, 7, 192-197.

41. Broadhurst, R.B.; Jones, W.J. Analysis of condensed tannins using acidified vanillin. J. Sci. Food Agric. 1978, 29, 788-792. [CrossRef]

42. Rebellato, A.P.; Bussi, J.; Silva, J.G.S.; Greiner, R.; Steel, C.J.; Pallone, J.A.L. Effect of different iron compounds on rheological and technological parameters as well as bioaccessibility of minerals in whole wheat bread. Food Res. Int. 2017, 94, 65-71. [CrossRef] [PubMed]

43. Katzenberg, M.A.; Saunders, S.R.; Abonyi, S. Bone Chemistry, Food and History: A Case Study from 19th Century Upper Canada. In Biogeochemical Approaches to Paleodietary Analysis; Ambrose, S.H., Katzenberg, M.A., Eds.; Kluwer Academic Publishers: New York, NY, USA, 2002.

44. Quintaes, K.D.; Amaya-Farfan, J.; Tomazini, F.M.; Morgano, M.A.; Mantovani, D.M. Migração de minerais de panelas brasileiras de aço inoxidável, ferro fundido e pedra-sabão (esteatito) para simulantes de alimentos. Ciência e Tecnologia de Alimentos 2004, 24, 397-402. [CrossRef]

45. Drago, S.R. Chapter 5-Minerals. In Nutraceutical and Functional Food Components: Effects of Innovative Processing Techniques; Galanakis, C.M., Ed.; Academic Press: London, UK, 2016; pp. 129-157; ISBN 978-0-12-805257-0.

46. Glahn, R. The use of Caco-2 cells in defining nutrient bioavailability: Application to iron bioavailability of foods. In Designing Functional Foods; McClements, D.J., Decker, E.A., Eds.; Elsevier: London, UK, 2009; pp. 340-361.

47. Glahn, R.P.; Wortley, G.M.; South, P.K.; Miller, D.D. Inhibition of iron uptake by phytic acid, tannic acid, and $\mathrm{ZnCl}_{2}$ : Studies using an In Vitro digestion/Caco-2 cell model. J. Agric. Food Chem. 2002, 50, 390-395. [CrossRef] [PubMed] 